\title{
Effect of chronic sodium nitrite administration on the expression of fibronectin in interstitial tissue of mice testis: An immunohistochemical study.
}

\author{
Sarah Amini ${ }^{*}$, Mohammad Reza Nikravesh ${ }^{1}$, Mehdi Jalali ${ }^{1}$, Alireza Fazel ${ }^{1}$, Ariane Sadr Nabavi ${ }^{\mathbf{2}}$ \\ ${ }^{1}$ Department of Anatomy and Cell Biology, Faculty of Medicine, Mashhad University of Medical Sciences, Mashhad, \\ Iran
}

${ }^{2}$ Department of Human Genetics, Faculty of Medicine, Mashhad University of Medical Sciences, Mashhad, Iran

\begin{abstract}
Background and Objectives: Nitrite and nitrate as common derivatives of nitrogen distribute throughout the body after consumption which consequently increases the content of their metabolites such as nitric oxide in biological fluids. High concentrations of nitrite and nitrate affect the fertility of men by changing the parameters of sperm. Half of the infertility problems are related to men. No study has been conducted on the possible effects of water contaminants on the expression of fibronectin in testicular interstitial tissue. Therefore, the present study aims to investigate the effects of chronic administration of sodium nitrite on the expression of fibronectin in interstitial tissue of mice testis using immunohistochemical assessments.

Methods: This was an animal laboratory study conducted on male mice $(n=24)$ who were divided into three groups: a control group and two treatment groups I and II. For 60 consecutive days, the control group received water containing no additives, and the treatment groups I and II water containing 3 and $50 \mathrm{mg} / \mathrm{L}$ of sodium nitrite, respectively. After sacrificing the animals, their testes were removed from both sides, and the right testicle was used for the immunohistochemical study and the left for real time polymerase chain reaction (RT-PCR) assessment.

Results: The amount of fibronectin mRNA was 0.92 fold in treatment group I and 0.8 fold in treatment group II, which showed no significant differences between the groups. Moreover, the qualitative expression of this protein in the interstitial tissue reduced insignificantly in treatment group II compared to the other groups $(\mathrm{p}=\mathbf{0 . 0 9 4})$.

Conclusion: Consuming water contaminated with sodium nitrite could not affect spermatogenesis through changing the expression of fibronectin in the interstitium of testis.
\end{abstract}

Keywords: Sodium nitrite, Interstitial tissue, Fibronectin, Mice, Testis.

Accepted on October 14, 2017

\section{Introduction}

Fibronectin is a permanent member of the basement membrane of all body organs, including the testes [1,2]. In the seminiferous tubules, fibronectin is expressed in the spermatic germ cells and peritubular myoid cells and is deposited in the extracellular matrix [3]. Many studies have shown that environmental pollutants such as tobacco can affect the expression of ECM proteins and fertility [4-6]. Nitrite is an endocrine disrupter and human studies have shown the effect of sodium nitrite on the quality of human sperm [7]. NO, which is a metabolite of nitrite, has a dual role in the synthesis of testosterone in culture media [8]. The concentration of nitrite in water should not be exceed $3 \mathrm{mg} / \mathrm{L}$ (ion) otherwise, it may cause oxidative stress associated with male infertility $[9,10]$. On the other hand, some studies demonstrated that ECM proteins can modulate steroidogenesis in vitro [11]. High concentrations of nitrite and nitrate affect the fertility of men by changing the parameters of sperm. Half of the infertility problems are related to men [12]. To our knowledge, no study has been conducted on the possible effects of water contaminants on the expression of fibronectin in testicular interstitial tissue. Therefore, the present study was aimed to investigate the effects of chronic administration of sodium nitrite on the expression of fibronectin in interstitial tissue of mice testis using immunohistochemical assessments.

\section{Materials and Methods}

Twenty four fertile male mice with average weight 21-24 g were purchased from the animal house of Mashhad School of Medicine and kept in suitable conditions. After becoming accustomed to their new environment, the animals were divided into a control and treatment groups I and II. The control group received pollutant-free water, and treatment 
groups I and II respectively received water plus 3 and $50 \mathrm{mg} / \mathrm{L}$ of sodium nitrite for 60 days.

After this period, the animals were weighed and euthanized by inhaling chloroform and cervical dislocation and then, their testes were cleared from surrounding fascias and weighed (Table 1). Their right testis stored in formalin 10\% and then in alcohol 70\% for IHC studies, and their left testis kept in RNAlater solution for the Real-Time PCR and then frozen at $-70^{\circ} \mathrm{C}$ for later use.

Table 1. Effects of sodium nitrite administration on body weight, testis weight and body weight and testis weight index.

\begin{tabular}{lllll}
\hline Groups & $\begin{array}{l}\text { Control } \\
\pm \text { SD) }\end{array}$ & $\begin{array}{l}\text { (Mean } \\
\pm \text { SD) }\end{array}$ & $\begin{array}{l}\text { Treatment I (Mean } \\
\pm \text { SD) }\end{array}$ \\
\hline $\begin{array}{l}\text { Body } \\
(\mathrm{B} . \mathrm{W})\end{array}$ & weight & $22.75 \pm 1.03$ & $22.75 \pm 1.03$ & $22.63 \pm 0.9$ \\
\hline $\begin{array}{l}\text { Testis } \\
(\mathrm{T} . \mathrm{W})\end{array}$ & weight & $0.96 \pm 0.1$ & $0.91 \pm 0.08$ & $0.92 \pm 0.09$ \\
\hline
\end{tabular}

Table 2. Grade of immunostaining reaction to fibronectin expression in testis.

\begin{tabular}{ll}
\hline Grade & Reaction \\
\hline 0 & Negative \\
\hline 1 & Very weak \\
\hline 2 & Weak \\
\hline 4 & Moderate \\
\hline
\end{tabular}

\section{The immunohistochemical technique}

To prepare samples for this technique, the routine steps of histological preparation were performed. Then, $5 \mu \mathrm{m}$ sections were transferred to Poly-L-Lysine slides, followed by IHC technique as briefly explained below [4]. At first cleansing and dehydration were carried out and then, to prevent internal peroxidase activity, the slides were incubated in $\mathrm{H}_{2} \mathrm{O}_{2} 3 \%$. The slides were rinsed with distilled water (DW) and heat-treated for antigen retrieval by bathing them in $100^{\circ} \mathrm{C}$ hot water. Once cooled at room temperature, DW and placed in Tris buffer containing Triton X-100 (\%0.025), and placed in a buffer containing $10 \%$ goat serum and $1 \%$ bovine serum albumin. The slides were exposed to fibronectin antibody $(1: 170)$ overnight. They were then rinsed again in Triton X-100 buffer. The slides were exposed to a secondary HRP- conjugated antibody at a 1:800 concentration at room temp for $2 \mathrm{~h}$. They were then placed in PBS containing di-amino-benzidine $(0.03$ g) and $\mathrm{H}_{2} \mathrm{O}_{2}$ and were rinsed three times in running water and DW. In order to create the background color, the slides were immersed for moments in hematoxylin and were then rinsed again in running and DW and passed through alcohol $90 \%$, $100 \%$ and xylene and were finally mounted. The slides were then examined using an Olympus optical microscope and the images were transferred to a computer for more accurate examination, and the intensity of the brown color created was visually graded according to Table 2 .

\section{Real-time PCR technique}

Total RNA Extraction: The testicular tissue that had been stored in RNA-later solution at $-70^{\circ} \mathrm{C}$, was thawed at room temp and underwent the following steps according to the RNA extraction kit protocol [12].

First, $35 \mathrm{mg}$ of the testicular tissue was transferred to a microtube and lysis buffer was added to it. The tissue was broken down, homogenized and vortex by pipetting. Chloroform was added to the microtube and vortexed again. The micro-tube was then centrifuged at $12000 \times \mathrm{g}$ for $12 \mathrm{~min}$ at $40^{\circ} \mathrm{C}$, and the supernatant was transferred to a new microtube. At this stage, $400 \mathrm{ml}$ of ethanol $70 \%$ was added to the micro-tube and spun. The mixture was transferred to a spin column and centrifuged at $13000 \times \mathrm{g}$ for $1 \mathrm{~min}$. The sediment was removed and PW was added to the columns and centrifuged at $13000 \times \mathrm{g}$ for one $\min$.

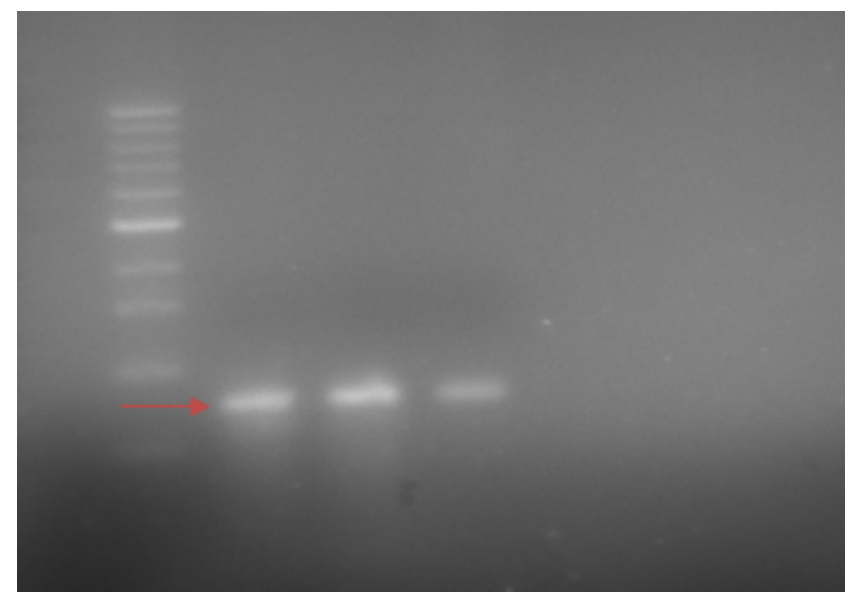

Figure 1. Acquired image from gel electrophoresis, after cDNA synthesis, that arrow shows fibronectin band (ladder 100).

The sample was spun at $13000 \times \mathrm{g}$ for $2 \mathrm{~min}$ to remove the buffer residue from the medium. The column was then transferred to a new $1.5 \mathrm{~mL}$ micro-tube. In the next step, $40 \mu \mathrm{L}$ of DEPC-treated water was added to the microtube and kept at room temperature and then spun again at $13000 \times \mathrm{g}$ for $1 \mathrm{~min}$ to obtain pure RNA and was kept at $-70^{\circ} \mathrm{C}$ until later stages.

cDNA Synthesis: The cDNA was synthesized as per the instructions and protocol provided by the cDNA Synthesis Easy Kit manufacturer [12]. In the first stage, $5 \mu \mathrm{L}$ of total RNA, $2 \mu \mathrm{L}$ of Oligo-dt and $1 \mu \mathrm{L}$ of Random hexamer were mixed in a microtube. Then, $5 \mu \mathrm{L}$ of DEPC-treated water was added to the mixture to reach a volume of $10 \mu \mathrm{L}$. The mixture was incubated at $65^{\circ} \mathrm{C}$ for $5 \mathrm{~min}$. Then, $10 \mu \mathrm{L}$ of RT premix was added into the mixture to reach a volume of $20 \mu \mathrm{L}$, and pipetting was performed several times. The mixture was incubated at $25^{\circ} \mathrm{C}$ for $10 \mathrm{~min}$ and at $50^{\circ} \mathrm{C}$ for $60 \mathrm{~min}$, and the reaction ended after $10 \mathrm{~min}$ at $70^{\circ} \mathrm{C}$, and the microtube was then frozen at $-20^{\circ} \mathrm{C}$. 
To ensure that the outcome was as intended, $5 \mu \mathrm{L}$ of the PCR product was electrophoresed on Agarose gel containing 0.5 $\mu \mathrm{g} / \mathrm{L}$ of ethidium bromide and the result was analyzed using a gel duct (Figure 1).

Primer design: To determine the amount of mRNA expression of fibronectin in the testicular tissues, Beacon Designer software was used to design four primers (Table 3). The sequence of each primer was found in the NCBI database. The exon and intron regions of the mRNA sequence of each gene were aligned together and the specificity of the primers' binding to the genes was ensured using BLAST software accessed through the NCBI website. To prevent the proliferation of the gene piece on the DNA chain, the melting temperature of the primers was selected close to each other, and one intron was placed in the gap between the primers.

Table 3. Sequence of the primers of the desired genes.

\begin{tabular}{lll}
\hline Gene & \multicolumn{2}{l}{ PRIMER SEQUENCE } \\
\hline \multirow{2}{*}{ Fibronectin } & forward & 5-TAGGAGAACAGTGGCAGAAAG-3 \\
\cline { 2 - 3 } & reverse & 5-CCATCGGGACTGGGTTCA-3 \\
\hline \multirow{2}{*}{ Beta-actin } & forward & 5-GGGAAATCGTGCGTGACA-3 \\
\cline { 2 - 3 } & reverse & 5-TCAGGAGGAGCAATGATCTTG-3 \\
\hline
\end{tabular}

Primer preparation: To perform the RT-PCR, 10 Pmol was collected from each primer. The primers were purchased from Macrogen Company (South Korea). The whole RT-PCR procedure was performed according to the protocol advised by the manufacturer. According to the protocol, a suitable amount of DW was added to each tube containing the forward and reverse primers to obtain a solution with a concentration of 100 from each to prepare a primer of $10 \mathrm{Pmol}$ dilution [12].

The real-time PCR technique: Before beginning the RT-PCR, the required band length was obtained by gel-electrophoresis to ensure the proper action of the primers (Figure 2) and a melting curve analysis was also performed. No primer dimer was formed during the amplification cycles. The main solution was prepared and the heating curve of the Applied Biosystems Step One was adjusted. Gene expression was measured semiquantitatively using SYBR Green fluorescence.

Changes in fibronectin expression in each group were compared with the beta-actin gene. The $\Delta \Delta \mathrm{CT}$ model was used to determine the relative changes in gene expression, and the results obtained were presented as fold change in relation to the controls [13].

\section{Statistical analysis}

The collected data were analyzed in statistical package of SPSS Windows, version 20. The normal distribution of the data was evaluated using the Kolmogorov-Smirnov test. The mean values of the quantitative variables were compared using the one-way ANOVA. Since the data were normally distributed, the Kruskal Wallis test was used for comparing the qualitative variables between the groups, and Mann-Whitney's test was used for the two-by-two comparison. The results were presented as mean \pm standard error of mean (SEM), and the level of statistical significance was set at $\mathrm{P}<0.05$ for all the tests.

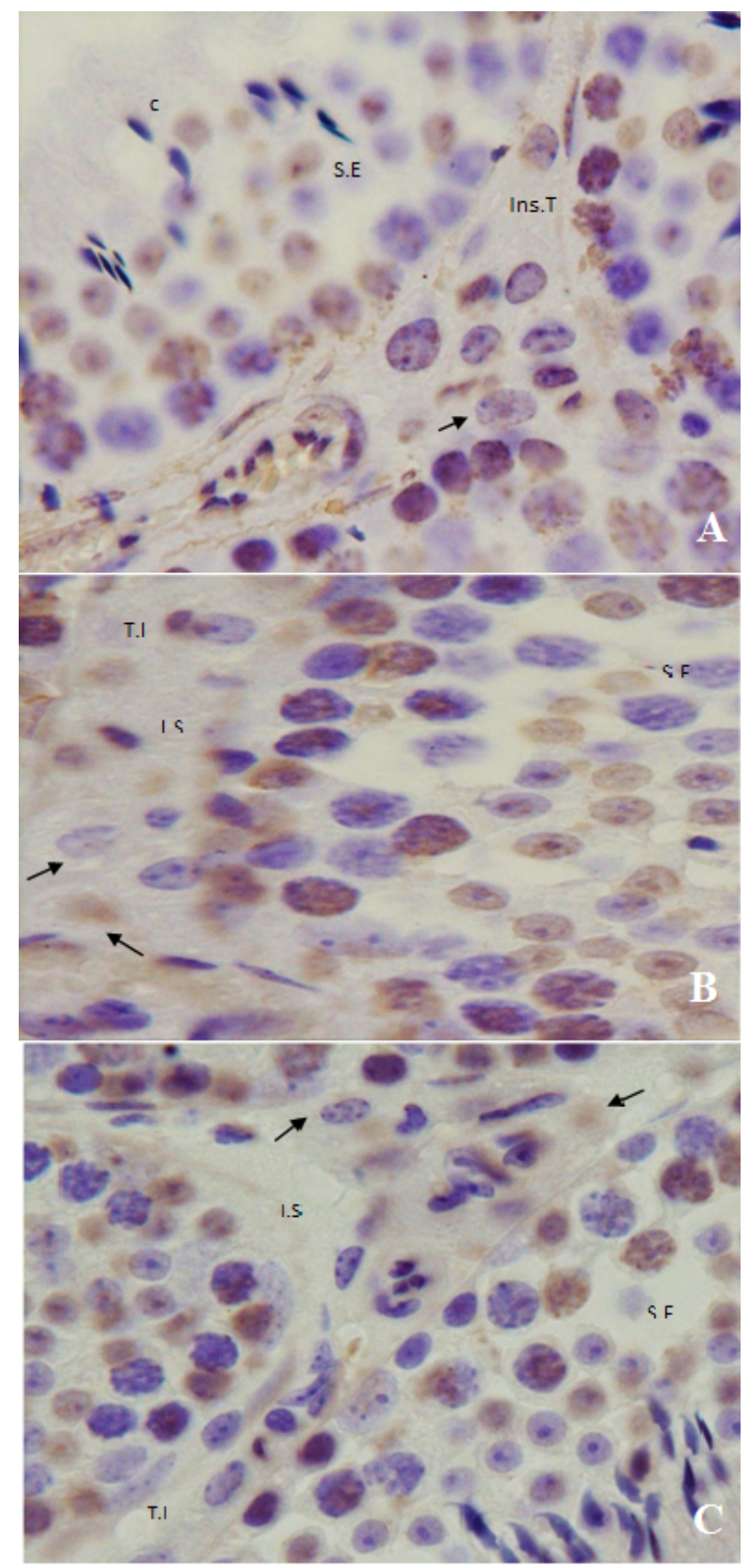

Figure 2. Photomicrographs show of seminiferous epithelium (S.E) and interstitial tissue (I.S) of the testes that have been treated with fibronectin antibody. Arrows show leydig cell. A) Control group (c); B) Treatment I (TI); C) Ttreatment II (TII); Hematoxylin counterstained, scale bar $100 \mu \mathrm{m}$.

\section{Results}

Body weight of mice was calculated and average weight of testes from each mouse was obtained so that mean weight of control group, treatment I and treatment II was $0.96 \pm 0.1,0.91$ \pm 0.08 and $0.92 \pm 0.09$ respectively [(Table 1$),(\mathrm{P}=0.5)$ ] Neither body weight nor testis weight to body weight index 
was significant different $(\mathrm{P}=0.9, \mathrm{P}=0.6$, respectively). The amount of fibronectin was 0.9 in treatment group I and 0.8 in treatment group II, without significant differences between them $[(\mathrm{P}>0.05)$, Figure 3].

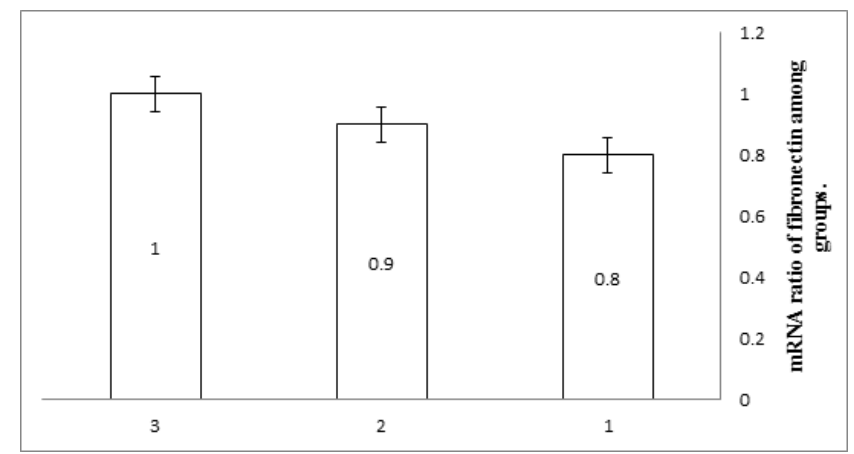

Figure 3. Relative transcription level of fibronectin mRNA expression in the testis of the control group, TI and TII. According to kolmogorovsmirnov test, real-time PCR data follows a normal distribution.

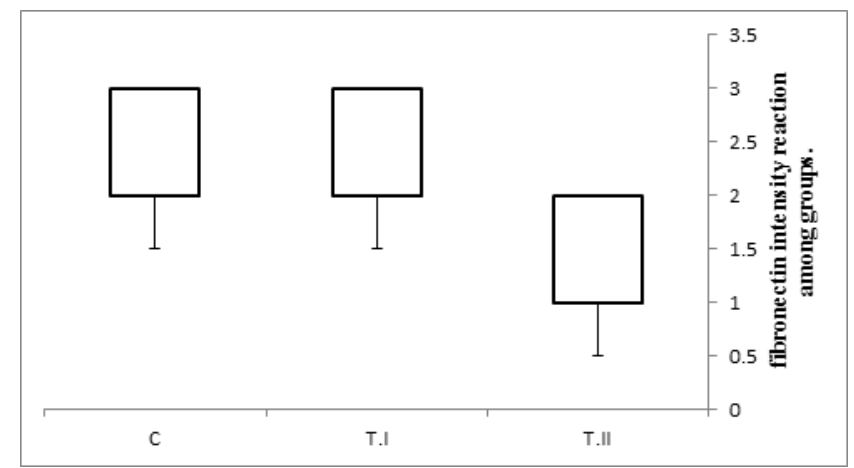

Figure 4. Diagram shows intensity reaction after testis slides exposed with anti-fibronectin antibody. Grading intensity was based on produced brown color. 4 was intense (dark brown), 3 was moderate, $2=$ weak (light brown), $1=$ very weak (pale brown) and 0 was negative (no reaction). There was no significant differences between groups. Median is presented in the form of $50 \%(25.75 \%), P=0.094)$.

The results of the analysis of variance showed that real-time PCR is not significant different between Groups. According to the IHC results, in the control group, the intensity of the expression of fibronectin was moderate to intense range in the testicular interestitium, where the leydig cell and connective tissue cells are located. The expression of fibronectin in the treatment I was similar to previous group but in treatment II, that of fibronectin was weak to moderate although was not significant $[(\mathrm{P}=0.094)$, Figure 4$]$.

\section{Discussion and Conclusion}

Our results showed that neither the body weight nor the testicular weight changed by the treatment with sodium nitrite. Moreover, the study showed that fibronectin is expressed in the ECM of the testicular interstitial tissue and, it also showed that oral usage of sodium nitrite over 60 days did not significantly alter the fibronectin expression in the interstitial tissue of the testis. The results showed that fibronectin was not only expressed throughout the interstitial tissue, but was focused around nucleus of leydig cells and blood vessels. Since fibronectin is synthesized by peritubular myoid cell, it may be the source of fibronectin from plasma. According to IHC analysis, in the control group, the intensity of reaction to fibronectin antibody was weak to moderate which was similar in the treatment I group, whereas in treatment II, the response to fibronectin antibody was weak to moderate but was not significant $[(\mathrm{P}=0.094)$, (Figure 2$)]$.

Aly et al. showed that treatment of animals with 100 to 200 $\mathrm{mg} / \mathrm{kg}$ B.W with sodium nitrite for 60 days caused a significant reduction in rat testicular weight and along with histopathological changes including atrophy, piknosis, and spermatogenesis disorder. They concluded that chronic exposure to sodium nitrate could damage the testicles and these effects are probably due to oxidative stress [9]. Panet et al. showed that water contaminated from 90 to $900 \mathrm{ppm}$ potassium nitrate for 35 days did not reduce the weight of testis and body weight of mice. However, activity of testicular enzymes changed and histopathological changes were observed. They concluded that testicular effects could not only be duo to water contamination [14].

The findings of Aly et al. did not support our findings which can be attributed to the higher doses used in their study. The findings of the Panet et al.'s study support our findings, while the length of the treatment was shorter. Our results did not show histopathological changes in the testes including leydig cell and also, testicular weight did not change. Battaglia et al. showed that testicular volume in normosperm men is higher than oligosperm men [8]. Since weight is directly related to volume, and the other hand testis is mainly made by seminiferous tubules. Therefore, it can be concluded that the chronic treatment of animals with sodium nitrite has no effect on spermatogenesis and steroidogenesis. Sabrino et al. investigated the effects of $\mathrm{NO} / \mathrm{NOS}$, testis homogenate and inactive IP administration of microorganism in rats in orchitis induction. Testicular damage, germ cell apoptosis, leydig cell hyperplasia and testis atrophy were observed that were accompanied by macrophage infiltration and increase of NO. They concluded that NO/NOS system contributed to the testicular damage [15].

The testicular tissue has unique properties such as a high level of unsaturated fatty acids and abundant cell divisions, which make it vulnerable to the excessive synthesis of free radicals. Moreover, the testicles require ROS and are equipped with antioxidant enzymes and free-radical scavenger [10,16]. Nitrite increase RNS in blood and thus can overcome the balance between free radicals and antioxidants through the nitritenitrate-nitric oxide pathway [6]. Nitrate reduces the renal activity of NOX by reducing the activity of angiotensin- 2 . Along with NOX, angiotensin- 2 and endothelin-1 cause the accumulation of collagen and fibronectin in tissues such as the kidney, heart, and lung [17].

Sodium nitrite appears to increase peripheral NO and its concentration beyond the physiological level, which consequently affects the peripheral vessels' endothelial cells and reduces endothelin expression and thereby causes changes 
in the expression of fibronectin. Assessing the degree to which the concentrations used in the present study can increase the blood level of NO and other metabolites requires further and more comprehensive studies, since their blood levels were not measured. And in this study chronic treatment with sodium nitrite did not change fibronectin expression in the testicular interstitium. Therefore, we concluded that water contaminated with $50 \mathrm{mg} / \mathrm{L}$ sodium nitrite is not be able to threaten male fertility through protein expression. Certainly, reproductive toxic potential of toxicants is dependent to dose and duration of the exposure. Therefore, it is recommended that higher sodium nitrite and invasive methods such as gavage or intraperitoneal injection of a drug are needed to clarify the role of sodium nitrite.

\section{Acknowledgment}

This paper is extracted from a $\mathrm{PhD}$ thesis registered and financially supported by Mashhad University of Medical Sciences, Mashhad, Iran (Grant No.: 930439).

Authors would like to thank to Mrs. Motejadded and Mrs. Tajik for their cooperation in conducting of this study. Moreover, the authors like to thank the staff at the animal facilities of the Mashhad University of Medical Sciences, Mashhad, Iran.

\section{References}

1. Moretti FA, Chauhan AK, Iaconcig A, Porro F, Baralle FE, Muro AF. A major fraction of fibronectin present in the extracellular matrix of tissues is plasma-derived. J Biol Chem 2007; 282: 28057-28062.

2. Kleinman HK, Philp D, Hoffman MP. Role of the extracellular matrix in morphogenesis. Curr Opin Biotechnol 2003 Oct; 14: 526-532.

3. Skinner MK, Stallard B, Anthony CT, Griswold MD. Cellular localization of fibronectin gene expression in the seminiferous tubule. Mol Cell Endocrinol 1989; 66: 45-52.

4. Mahdi Shariati K, Mohammad Reza N, Mehdi J, Alireza F, Mojtaba S, Bideskan AE. Effects of maternal nicotine exposure on expression of laminin alpha 5 in lung tissue of newborn. Pak J Biol Sci 2012; 15: 1168-1175.

5. Shariati Kohbanani M, Taghavi MM, Shabanizadeh A, Jafari Naveh HR, Taghipour Z, Kazemi Arababadi M. Different ideas associated renal malformation and laminin $\alpha 5$ expression caused by maternal nicotine exposures. Cell Mol Biol 2016; 62: 100-104.

6. Sedha S, Kumar S, Shukla S. Role of Oxidative Stress in Male Reproductive Dysfunctions with Reference to Phthalate Compounds. Urol J 2015; 12: 2304-2316.

7. Zaki A, Ait Chaoui A, Talibi A, Derouiche AF, Aboussaouira T, Zarrouck K, Chait A, Himmi T. Impact of nitrate intake in drinking water on the thyroid gland activity in male rat. Toxicol Lett 2004; 147: 27-33.
8. Battaglia C, Giulini S, Regnani G, Madgar I, Facchinetti F, Volpe A. Intratesticular Doppler flow, seminal plasma nitrites/nitrates, and nonobstructive sperm extraction from patients with obstructive and nonobstructive azoospermia. Fertil Steril 2001; 75: 1088-1094.

9. Aly HA, Mansour AM, Abo-Salem OM, Abd-Ellah HF, Abdel-Naim AB. Potential testicular toxicity of sodium nitrate in adult rats. Food Chem Toxicol 2010; 48: 572-578.

10. Nakamura BN, Lawson G, Chan JY, Banuelos J, Cortés MM, Hoang YD, Ortiz L, Rau BA, Luderer U. Knockout of the transcription factor Nrf2 disrupts spermatogenesis in an age-dependent manner. Free Radic Biol Med 2010; 49: 1368-1379.

11. Diaz ES, Pellizzari E, Meroni S, Cigorraga S, Lustig L, Denduchis B. Effect of extracellular matrix proteins on in vitro testosterone production by rat Leydig cells. Mol Reprod Dev 2002; 61: 493-503.

12. Pahang H, Nikravesh MR, Jalali M, Ebrahimzadeh Bideskan A, Zargari P, Sadr Nabavi A. Fibronectin regulation by vitamin $\mathrm{C}$ treatment in kidneys of nicotinic mice offspring. Iran Red Crescent Med J 2014; 16: e17056.

13. Pfaffl MW. A new mathematical model for relative quantification in real-time RT-PCR. Nucleic Acids Res 2001; 29: e45.

14. Pant N, Srivastava SP. Testicular and spermatotoxic effect of nitrate in mice. Hum Exp Toxicol 2002; 21: 37-41.

15. Jarazo Dietrich S, Fass MI, Jacobo PV, Sobarzo CM, Lustig L, Theas MS. Inhibition of NOS-NO System Prevents Autoimmune Orchitis Development in Rats: Relevance of NO Released by Testicular Macrophages in Germ Cell Apoptosis and Testosterone Secretion. PLoS One 2015; 10: e0128709.

16. Başar MM, Kisa U, Tuğlu D, Yilmaz E, Başar H, Cağlayan $\mathrm{O}$, Batislam E. Testicular nitric oxide and thiobarbituric acid reactive substances levels in obstructive azoospermia: a possible role in pathophysiology of infertility. Mediators Inflamm 2006; 2006: 27458.

17. Jerkić M, Miloradović Z, Jovović Đ,Mihailović-Stanojević $\mathrm{N}$, Elena JVR, Nastić-Mirić D. Relative roles of endothelin-1 and angiotensin II in experimental postischaemic acute renal failure. Nephrology Dialysis Transplantation 2004; 19: 83-94.

\section{*Correspondence to}

Sarah Amini

Department of Anatomy and Cell Biology

Faculty of Medicine

Mashhad University of Medical Sciences

Iran 